\title{
New synonyms and combinations in Drimia Jacq. (Hyacinthaceae) in southern Africa
}

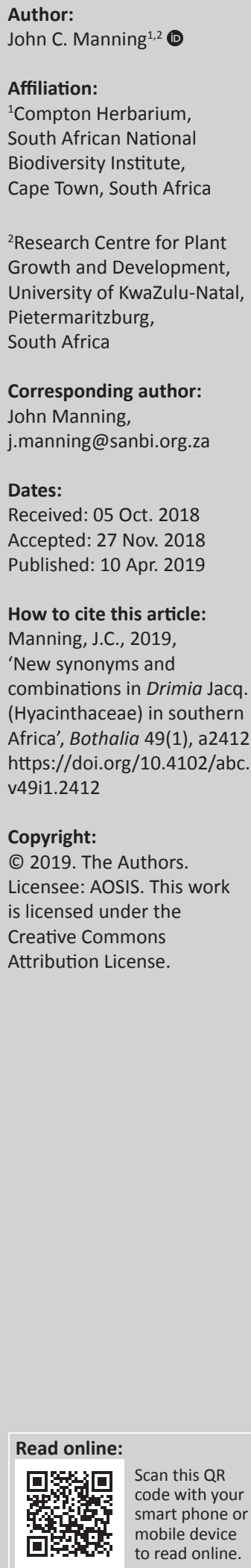

Background: Ongoing systematic studies in the African flora necessitate periodic nomenclatural adjustments and corrections.

Objectives: To effect requisite nomenclatural changes.

Method: Relevant literature was surveyed and relevant material was examined.

Results: Nomenclatural adjustments are provided for recently described taxa of Hyacinthaceae subfamily Urgineoideae in order to accommodate them in the alternative classification system in use in South African herbaria.

Conclusion: A broadly circumscribed Drimia Jacq. has the advantages of nomenclatural stability and utility. The newly described segregate genera Austronea Mart.-Azorín et al. and Zingela N.R.Crouch et al. are formally included in Drimia, and A. densiflora Mart.-Azorín et al., A. hispidoplicata Mart.-Azorín et al. and A. pinguis Mart.-Azorín et al. are transferred to that genus as D. densiflora (Mart.-Azorín et al.) J.C.Manning \& Goldblatt, D. hispidoplicata (Mart.-Azorín et al.) J.C.Manning \& Goldblatt and D. pinguis (Mart.-Azorín et al.) J.C.Manning \& Goldblatt, respectively, whereas $A$. grandiflora Mart.-Azorín et al. and A. linearis Mart.-Azorín et al. are treated as synonyms of $D$. vermiformis J.C.Manning \& Goldblatt; A. olifanta Mart.-Azorín et al. is treated as a synonym of $D$. barkerae Oberm. ex J.C.Manning \& Goldblatt; and A. papillosa Mart.Azorín et al. and A. pygmaea (A.V. Duthie) Mart.-Azorín et al. are treated a synonyms of $D$. virens (Schltr.) J.C.Manning \& Goldblatt. Zingela pooleyorum N.R.Crouch is considered to be conspecific with Urginea zambesiaca Baker, for which the new combination D. zambesiaca (Baker) J.C.Manning \& Goldblatt is provided. The combination D. zebrina (Mart.-Azorín et al.) J.C.Manning \& Goldblatt is provided for an allied species. Examination of recent collections of Ornithogalum toxicarium C.Archer \& R.H.Archer confirms that it is actually a species of Drimia and it is accordingly transferred to that genus as D. toxicaria (C.Archer \& R.H.Archer) J.C.Manning \& Goldblatt.

Keywords: Austronea; nomenclature; southern Africa; synonym; taxonomy; Urginea; Vera-duthiea; Zingela.

\section{Introduction}

Zingela N.R.Crouch et al. (Crouch et al. 2018) and Austronea Mart.-Azorín et al. (Martínez-Azorín et al. 2018a) are two recently described southern African genera of Hyacinthaceae subfamily Urgineoideae (Angiosperm Phylogeny Group [APG] 2003), alternatively treated as Asparagaceae subfamily Scilloideae tribe Urgineeae (APG 2009, 2016). They were named as part of an ongoing generic reclassification of the subfamily that derives from an as-yet only partially published molecular phylogenetic analysis of the group. This classification is increasingly divergent from the conservative interpretation proposed by Manning, Goldblatt and Fay (2004) that adopted a larger, inclusive circumscription of the genus Drimia Jacq. The latter classification is the preferred option among southern African botanists, where it has been adopted by the major herbaria in the country (e.g. BOL, NBG, PRE) and in recent publications on the flora (e.g. Manning \& Goldblatt 2012, 2018; Snijman 2013; Van Jaarsveld \& Eggli 2016). The two genera Austronea and Zingela accord, respectively, with Drimia sects. Marginatae and Thuranthos (= Vera-duthiea Speta) in the recent revision of the southern African species of Drimia (Manning \& Goldblatt 2018).

The application of molecular phylogenetic techniques in the family provided testable hypotheses of relationships among the species for the first time. Stimulated by the initial findings (Pfosser \& Speta 1999), the Austrian taxonomist Franz Speta (1998) rejected the concept of a more broadly circumscribed Drimia that had been gaining acceptance among taxonomists working actively on the African elements (e.g. Jessop 1977; Stedje \& Thulin 1995) in favour of narrowly circumscribed genera as determined by the clades resolved in the first phylogeny generated for the family. 
This analysis included just 15 samples of Urgineoideae, representing as many taxa out of a current estimated total of \pm 120 species (Manning \& Goldblatt 2018). Until this time, genera in the subfamily had been recognised based on differences in floral morphology, primarily the ramification of the inflorescence, the degree of fusion of the perianth, and the attachment and mode of dehiscence of the anthers (e.g. Baker 1897; Jessop 1977). The progressive discovery of new species that blurred many of these differences highlighted the inadequacy of the conventional taxonomy of the time, prompting botanists to broaden the circumscription of Drimia to include the segregates Tenicroa Raf., Thuranthos C.H.Wright and Urginea Steinh, but retaining the morphologically more distinct genera Litanthus Harv., Schizobasis Baker and Rhadamanthus Salisb (Jessop 1977; Stedje \& Thulin 1995).

The emerging phylogenies appeared to provide adequate justification for the splitting of an enlarged Drimia into smaller, evidently monophyletic genera, and on this basis Speta (1998) recognised 13 genera in a subfamily in which contemporary authors recognised just five. Increased sampling, however, continues to reveal that some of these smaller segregates are themselves not monophyletic, demanding the description of additional, smaller segregates in order to maintain generic monophyly (see Manning \& Goldblatt 2018 for a summary). This applies to even the smallest possible genera: just a few years after establishing the ditypic genus Sagittanthera Mart.-Azorín et al. (Martínez-Azorín et al. 2013), its authors discovered that the two member species were not in fact sister taxa, despite the superficial morphological similarity between them, and perforce transferred one species to a new monotypic genus Auolstemon Mart.-Azorín et al. (Martínez-Azorín et al. 2017). As current sampling stands, the number of genera in Urgineoideae recognised by Martínez-Azorín and coworkers is more than 20 and increasing. The justification for this plethora of genera is solely the application of the principle of monophyly as driven by the initial decision of Speta (1998) to implement a taxonomy based on an incomplete phylogeny that included little more than $10 \%$ of the species known at the time. Additional considerations like utility, nomenclatural stability and phylogenetic support, as identified by Backlund and Bremer (1998), have played no role in informing what is becoming an increasingly fragmented taxonomy. Indeed, it seems likely that the initial decision to recognise smaller genera may have been a premature one that has driven subsequent events. It is possibly significant that two of the authors involved in this process have also proposed splitting the well-established genus Iris L. (Iridaceae) (260-300 spp.) into at least 23 smaller segregates (Mavrodiev et al. 2014). This proposal has, unsurprisingly, been ignored.

In contrast, a more broadly circumscribed Drimia is readily diagnosed and identified, and it permits the recognition of numerous infrageneric groups as required to accommodate the morphological complexity in the group without affecting nomenclatural stability (Manning \& Goldblatt 2018). Claims that this option is 'based on disputable phylogenetic data' (Crouch et al. 2018) are inexplicable and patently unjustified (Ali et al. 2013; Buerki et al. 2012).
Here we provide new combinations and other nomenclatural adjustments necessitated by the appearance of three recent publications describing yet another two genera in the subfamily (Crouch et al. 2018; Martínez-Azorín et al. $2018 \mathrm{a}, \mathrm{b})$. In addition, the examination of paratypes and more recent collections of Ornithogalum toxicarium C.Archer \& R.H.Archer (Archer \& Archer 1999) revealed that this species is misplaced in subfamily Ornithogaloideae and that it is actually a species of Drimia, and we accordingly transfer the name to that genus.

\section{Taxonomic treatment}

Drimia Jacq., Collectanea Suppl.: 38 (1797). Type species: Drimia elata Jacq.

Sect. Capitatae J.C.Manning \& Goldblatt in Strelitzia 40: 76 (2018). Type: Drimia marginata (Thunb.) Jessop

Austronea Mart.-Azorín et al. in Phytotaxa 365: 105 (2018a), syn. nov. Type: Austronea marginata (Thunb.) Mart.-Azorín et al. = Drimia marginata (Thunb.) Jessop

Note: The new genus Austronea coincides exactly with the circumscription of Drimia sect. Capitatae as described by Manning and Goldblatt (2018), but includes several newly described species for which we provide the necessary combinations or synonymy in Drimia.

Drimia barkerae Oberm. ex J.C.Manning \& Goldblatt in Bothalia 33: 109 (2003). Type: South Africa, Western Cape, ' $5 \mathrm{~km}$ south west of Eendekuil, Draaihoek farm, open clay flats', 13 Oct 2001, Manning 2655A (NBG, holo.!; PRE!, iso.).

Austronea olifanta Mart.-Azorín et al. in Phytotaxa 365: 119 (2018a), syn. nov. Type: South Africa, Western Cape, 'near Clanwilliam-Citrusdal-Cederberg road crossing', 23 Sept 2013, Martínez-Azorín et al. $828 b$ (GRA, holo.; ABH, iso.).

Note: Austronea olifanta was distinguished from D. barkerae on minor vegetative and floral differences, none of which is convincing to us and some of which are not strictly true, and until the matter is more convincingly resolved we treat them as conspecific. This extends the known range of D. Barkerae only very slightly, from the western foot of the Olifants River Mountains into the Olifants River Valley.

Drimia densiflora (Mart.-Azorín et al.) J.C.Manning \& Goldblatt, comb. nov. Austronea densiflora Mart.-Azorín et al. in Phytotaxa 365: 109 (2018a). Type: South Africa, Western Cape, 'Oudshoorn, Grootkop Nature Reserve', 28 Sep 2011, Martínez-Azorín et al. 891 GRA, holo.; ABH, iso.).

Note: Drimia densiflora is morphologically anomalous in the section in its very short pedicels, forming a congested, subspicate raceme rather than the corymbose-capitate raceme that characterises the other species. Its association with other species in the group is impossible to determine on morphology alone, and we assume that it was described in 
Austronea based on phylogenetic data. On the basis of its morphology, Austronea densiflora keys to Drimia sect. Ledebouriopsis in the recent revision of the genus by Manning and Goldblatt (2018). Here it resembles both D. salteri (Compton) J.C.Manning \& Goldblatt from the south-western mountains of the Western Cape, from which it is distinguished by its shorter inflorescence and shorter, thicker leaf, and D. barbata J.C.Manning \& Goldblatt from the Richtersveld, which it closely resembles in the size and shape of its inflorescence but which has a basally puberulous scape, flowers with a pubescent cup and a longer, more slender leaf.

Drimia hispidoplicata (Mart.-Azorínet al.) J.C.Manning \& Goldblatt, comb. nov. Austronea hispidoplicata Mart.-Azorín et al. in Phytotaxa 365: 114 (2018a). Type: South Africa, Northern Cape, 'ca. $10 \mathrm{~km}$ NE of Kotzesrus on the way to Garies', 20 Aug 2017 (in leaf), Martínez-Azorín et al. 1788 (GRA, holo.; $\mathrm{ABH}$, iso.).

Drimia pinguis (Mart.-Azorín et al.) J.C.Manning \& Goldblatt, comb. nov. Austronea pinguis Mart.-Azorín et al. in Phytotaxa 365: 121 (2018a). Type: South Africa, Western Cape, 'Rooinek Pass, ca. 18 km S of Laingburg on R323', 04 May 2018 (fl. ex hort. Spain), Martínez-Azorín et al. $1342 b$ (GRA, holo.; $\mathrm{ABH}$, iso.).

Note: see under D. vermiformis below.

Drimia vermiformis J.C.Manning \& Goldblatt in MartínezAzorín \& Crespo in Taxon 63: 1330 (2014). Austronea vermiformis (J.C.Manning \& Goldblatt) Mart.-Azorín et al. in Phytotaxa 365: 108 (2018a). Type: South Africa, Western Cape, 'Clanwilliam Dam, picnic site along N7 near wall', 03 Aug 1987, P.L. Perry 3587 (NBG [leaf only], holo.!).

Austronea grandiflora Mart.-Azorín et al. in Phytotaxa 365: 112 (2018a), syn. nov. Type: South Africa, Northern Cape, '2 km from Sutherland-Calvinia R354 on turnoff to Bo-Visrivier', 15 Apr 2014 (fl. ex hort. Spain), Martínez-Azorín et al. 828b (GRA, holo.; $\mathrm{ABH}$, iso.).

Austronea linearis Mart.-Azorín et al. in Phytotaxa 365: 116 (2018a), syn. nov. Type: South Africa, Western Cape, 'ca. 3 km from Calitzdorp on road to Oudshoorn', 28 Sept 2011, Martínez-Azorín et al. 828b (GRA, holo.; ABH, iso.).

Note: Manning and Goldblatt (2018), in their recent monograph of Drimia in Southern Africa, included in their circumscription of $D$. vermiformis the material segregated as Austronea linearis by Martínez-Azorín et al. (2018a) on the basis of its slightly narrower leaves, as well as that from the Roggeveld that they recognised as A. grandiflora on the basis of its slightly larger flowers and less flattened leaves. We have re-examined the relevant collections in light of this but remain unconvinced that there is adequate reason to segregate them from $D$. vermiformis. We accordingly relegate these names to synonymy. In contrast, collections with unusually short, succulent leaves that were identified as the new species A. pinguis by Martínez-Azorín et al. (2018) in our opinion represent a distinct species. We had excluded the single collection of this taxon that was available to us from our circumscription of $D$. vermiformis but were unable to formally describe it as it lacked flowers.

Drimia virens (Schltr.) J.C.Manning and Goldblatt in Goldblatt and Manning in Strelitzia 9: 712 (2000). Urginea virens Schltr. in J. Bot., British and Foreign 35: 433 (1897). Austronea pygmaea (Schltr.) Mart.-Azorín et al. in Phytotaxa 365: 108 (2018a). Type: South Africa, Western Cape, 'Cold Bokkeveld, Tweefontein', 24 Jan 1897, Schlechter 10127 (BOL, lecto.!, designated by Manning and Goldblatt in Bothalia 37: 184 (2007); E, GRA!, BM, K!, L, P, PRE!, S!, Z, isolecto.).

Urginea pygmaea A.V.Duthie in Ann. Univ. Stell. 6A: 10 (1928), syn. nov. Fusifilum pygmaeum (A.V.Duthie) Speta in Phyton 38: 69 (1998). Drimia pygmaea (A.V.Duthie) J.C.Manning and Goldblatt in Strelitzia 40: 77 (2018). Austronea pygmaea (Schltr.) Mart.-Azorín et al. in Phytotaxa 365: 108 (2018a). Type: South Africa, Western Cape, Cape Town (3318): 'Stellenbosch Flats', (-DD), 03 Jun 1926, Duthies. n. STE1603a (NBG, lecto.!, designated by Martínez-Azorín et al. in Phytotaxa 201: 169 [2015]).

Austronea papillosa Mart.-Azorín et al. in Phytotaxa 365: 121 (2018a), syn. nov. Type: South Africa, Northern Cape, 'Naip se Berg', 28 Sept 2015, Martínez-Azorín et al. 1260 (GRA, holo.; $\mathrm{ABH}$, iso.).

Note: Austronea papillosa was segregated from $D$. virens on the basis of the papillate peduncle and pedicels; however, this condition is also found in populations of $D$. virens from Vanrhynsdorp and the Cederberg, as described by Manning and Goldblatt (2018), who included paratype material of A. papillosa under that species. We are not able to differentiate two taxa on this basis and regard them as one.

We, however, follow Martínez-Azorín et al. (2018a), who concluded that we had erred in our identification of the type of $D$. virens as conspecific with Urginea minor (sect. Physodia). The differences between the two species are not always clear in herbarium material and a similar error had earlier been made by Speta (1998). From their examination of isotype material at Edinburgh, Martínez-Azorín et al. (2018a) concluded that the flowers lack the fusiform filaments that are diagnostic for sect. Physodia. The name D. virens thus becomes the earliest name for the species in sect. Capitatae that we treated as D. pygmaea, and Drimia minor remains the earliest name for the species in sect. Physodia that we treated there under the name $D$. virens.

Sect. Macrocentrae J.C.Manning and Goldblatt in Strelitzia 40: 19 (2018). Type: Drimia macrocentra Baker

Drimia toxicaria (C.Archer \& R.H.Archer) J.C.Manning and Goldblatt, comb. nov. Ornithogalum toxicarium C.Archer and R.H.Archer in S. Afr. J. Bot. 65: 431 (1999). Albuca toxicaria (C.Archer \& R.H.Archer) J.C.Manning and Goldblatt in Manning et al. in Taxon 58: 92 (2009). Type: South Africa, 
Western Cape, 'Beaufort West Dist., Farm RystKuil 351', 08 Oct 1983, Retief E Reid 239 (PRE [flowering plants and sterile plants only, excluding the fruiting plant and detached infructescence], lecto.!, designated here).

[Urginea longicollis Oberm. ms. Acocks 2444 (PRE), Jouberts.n. (PRE)]

Note: This diminutive species was described in Ornithogalum subg. Urophyllon (Salisb.) Baker on account of its evidently spurless bracts, free tepals with median longitudinal stripe, erect style with small stigma, large tricostate capsules with adherent perianth and large flat seeds (Archer \& Archer 1999). The very small bracts are, however, anomalous here. The species was transferred to Albuca subg. Namibiogalum (U.Mull.Doblies \& D.Müll.-Doblies) J.C.Manning \& Goldblatt, along with other species of Ornithogalum with similar floral and fruit morphology, by Manning et al. (2004) in their revised generic classification of subfamily Ornithogaloideae. Recent collections of the species that we have seen, however, confirm the initial conclusions of A.A.Obermeyer that it is in fact a species of Drimia. This is clear from the presence of a short but evident spur on the lowermost bracts of some paratype and other specimens, the uni-nerved tepals in the type and all other collections, and the winged seeds with loose testa. Examination of the type, which comprises several plants, shows it to be a mixed gathering, with the flowering and sterile plants conforming to the protologue description and accompanying illustration but the fruiting material representing a species of Albuca, as is evident from the large bracts, multi-nerved tepals and prismatic style. We accordingly exclude the fruiting material and lectotypify the name against the flowering and sterile material only (Turland et al. 2018: Art. 9.14). The relationships of the species in Drimia are not immediately apparent, but the congested, relatively longlived flowers without bracteoles and the moderately large capsules with perianth persisting below the developing fruit for somewhile suggest a possible relationship with $D$. sanguinea (Schinz) Jessop (sect. Macrocentrae).

\section{Additional material seen}

Namibia. 2716 (Witputz): slope of Tsaus Mtns, (-AA), 26 Sep 1996, C. E J. Mannheimer 317 (PRE); Rosh Pinah, S of Sebrafontein, (-DD), 28 Aug 2003, P. Bruyns 9486 (NBG). 2719 (Tränental):Tränental KEE 299 (AB), 13 Oct 1970 (fruiting), Jouberts.n. (PRE).

South Africa. Northern Cape. 2820 (Augrabies): Augrabies, Renosterkop, (-CB), 17 Sep 1990, P. Perry 3800 (NBG). 2822 (Glen Lyon): near Postmasburg, (-BD), 18 Sep 1937, J. Acocks 2444 (PRE). 2919 (Pofadder): Aggenys, plateau of Achab se Berg, (-AC), without date, P. Desmet2023 (NBG).

Sect. Physodia (Salisb.) J.C.Manning \& Goldblatt in Strelitzia 40: 92 (2018). Physodia Salisb., Gen. Pl.: 37 (1866). Urginea sect. Physodia (Salisb.) Baker in J. Linn. Soc., Bot. 13: 216 (1873). Type: Physodia pusilla (Jacq.) U.Müll.-Doblies = Drimia physodes (Jacq.) Jessop
Fusifilum Raf., Fl. Tellur. 2: 27 (1837). Type: Fusifilum physodes (Jacq.) Speta $=$ Drimia physodes (Jacq.) Jessop

Drimia minor (A.V.Duthie) Jessop in J. S. Afr. Bot. 43: 306 (1977). Urginea minor A.V.Duthie in Ann. Stell. Univ. 6, A(2): 11 (1928). Physodia minor (A.V.Duthie) U.Müll.-Doblies et al. in Müller-Doblies and Müller-Doblies in Feddes Repert. 107: 520 (1996). Fusifilum minus [as 'minor'] (A.V.Duthie) Speta in Phyton 38: 69 (1998). Type: South Africa, Western Cape, Cape Town, 'Stellenbosch Flats', Mar 1924, Duthies. n. STE1546 (NBG, holo.!).

(Drimia virens sensu Manning \& Goldblatt in Strelitzia 40: 100 [2018], excl. type)

Sect. Thuranthos (C.H.Wright) J.C.Manning \& Goldblatt in Strelitzia 40: 62 (2018). Thuranthos C.H.Wright in Kew Bull. 1916: 233 (1916). Type: Thuranthos macranthus (Baker) C.H.Wright = Drimia macrantha (Baker) Baker

Vera-duthiea Speta in Phyton 56: 154 (2016). Duthiea Speta in Stapfia 75: 170 (2001), nom. illeg. Type: V. sengalensis (Kunth) Speta $=$ Drimia senegalensis (Kunth) J.C.Manning \& Goldblatt

Zingela N.R.Crouch et al. in Phytotaxa 371: 36 (2018), syn. nov. Type: Zingela pooleyorum N.R.Crouch et al. = Drimia zambesiaca (Baker) J.C.Manning \& Goldblatt

Drimia zambesiaca (Baker) J.C.Manning \& Goldblatt, comb. nov. Urginea zambesiaca Baker in J. Linn. Soc. Bot. 13: 223 (1873). Thuranthos zambesiacum (Baker) Kativu in Kativu and Drummond in Kirkia 15: 113 (1994). Type: Mozambique, 'Expedition Island', without date, Kirk s.n. (K, holo.-image!).

Zingela pooleyorum N.R.Crouch et al. in Phytotaxa 371: 36 (2018), syn. nov. Type: South Africa, KwaZulu-Natal, 'Ndumo [Ndumu] Game Reserve', 15 Oct 1969, Pooley 661 (NU, holo.!).

(Drimia indica sensu Goldblatt \& Manning [2018], non [Roxb.] Jessop)

Note: In their revision of Drimia in Southern Africa, Manning and Goldblatt (2018) followed custom in identifying specimens from coastal KwaZulu-Natal, including Pooley 661 (NU), as D. indica. This is evidently an error, as Crouch et al. (2018) have concluded that D. indica is strictly an Indian species based on an as-yet unpublished phylogeny. These authors accordingly described the new genus and species Zingela pooleyorum for the plants from KwaZulu-Natal, stating that the taxon is likely also to occur in southern Mozambique. And indeed Manning and Goldblatt (2018) considered that Urginea zambesiaca from Expedition Island in Mozambique was conspecific with the KwaZulu-Natal plants, in which case it is the earliest available name for Z. pooleyorum, which thus becomes a synonym. Zingela pooleyorum is a perfect match for the illustration of Urginea zambesiaca provided by Kativu and Drummond (1994), which shows the spathulate bulb scales, relatively short pedicels, and suberect, filiform filaments that are diagnostic for the species. 
Drimia zebrina (Oberm. ex Mart.-Azorín et al.) J.C.Manning \& Goldblatt, comb. nov. Vera-duthiea zebrina Oberm. ex Mart.Azorín et al. in Phytotaxa 375: 285 (2018b). Type: South Africa, KwaZulu-Natal, 'Ndumo [Ndumu] Game Reserve, Ndumo [Ndumu] Hill', 4 Nov 1986, E. Pooley 127 (NU, holo.; $\mathrm{NH}$, iso.).

Note: This species is evidently closely allied to D. basutica, differing from it in its linear-canaliculate leaves with rounded lower surface, and smaller flowers with filiform filaments not widened towards the base.

\section{Acknowledgements Competing interests}

The author declares that he has no financial or personal relationships that may have inappropriately influenced him in writing this article.

\section{References}

Ali, S.S., Pfosser, M., Wetschnig, W., Martínez-Azorín, M., Crespo, M.B. \& Yu, Y., 2013, 'Out of Africa: Miocene dispersal, vicariance, and extinction within Hyacinthaceae subfamily Urgineoideae', Journal of Integrative Plant Biology 55, 950-964. https:// doi.org/10.1111/jipb.12065

Angiosperm Phylogeny Group (APG), 2003, 'An update of the Angiosperm Phylogeny Group classification for the orders and families of flowering plants: APG II', Botanical Journal of the Linnean Society 141, 399-436. https://doi. org/10.1046/j.1095-8339.2003.t01-1-00158.x

Angiosperm Phylogeny Group (APG), 2009, 'An update of the Angiosperm Phylogeny Group classification for the orders and families of flowering plants: APG III', Botanical Journal of the Linnean Society 161, 105-121. https://doi.org/10.1111/ j.1095-8339.2009.00996 $x$

Angiosperm Phylogeny Group (APG), 2016, 'An update of the Angiosperm Pylogeny Group classification for the orders and families of flowering plants: APG IV', Botanical Journal of the Linnean Society 181, 1-20.

Archer, C. \& Archer, R.H., 1999, 'A new species of Ornithogalum subgenus Urophyllon (Hyacinthaceae) from central South Africa and southern Namibia', South African Journal of Botany 65(5-6), 431-433. https://doi.org/10.1016/S0254-6299(15) 31035-8

Backlund, A. \& Bremer, K., 1998, 'To be or not to be - Principles of classification and monotypic plant families', Taxon 47(2), 391-400. https://doi.org/10.2307/1223768

Baker, J.G., 1873, 'Revision of the genera and species of Scilleae and Chlorogaleae', Journal of the Linnean Society, Botany 13, 209-292.

Baker, J.G., 1897, 'Liliaceae', in W.T. Thiselton-Dyer (ed.), Flora capensis, vol. 6, pp. 253-528, L. Reeve, Kent.

Buerki, S., Jose, S., Yadav, S.R., Goldblatt, P., Manning, J.C. \& Forest, F., 2012, 'Contrasting biogeographic and diversification patterns in two Mediterraneantype ecosystems', PLoS One 7, 1-11.

Crouch, N.R., Martínez-Azorín, M., Crespo, M.B., Pinter, M. \& Alonso-Vargas, M.A., 2018, 'Zingela (Asparagaceae, Scilloideae), a distinct new urgineoid genus from
KwaZulu-Natal, South Africa', Phytotaxa 371, 33-41. https://doi.org/10.11646/ KwaZulu-Natal, So
phytotaxa.371.1.4

Duthie, A.V., 1928, 'Contribution to our knowledge of the Stellenbosch flora. The species of Urginea of the Stellenbosch flats', Annale van die Universiteit van species of Urginea of the Stellen
Stellenbosch 6, Sect. A, 2, 3-16.

Goldblatt, P. \& Manning, J.C., 2000, Cape plants: A conspectus of the Cape flora of South Africa, Strelitzia 9, National Botanical Institute, Cape Town and Missouri Botanical Garden, St Louis.

Jacquin, N.J., 1797 ['1796'], Collectaneorum supplemtum, Wappler, Vienna.

Jessop, J.P., 1977, 'Studies in the bulbous Liliaceae in South Africa 7: The taxonomy of Drimia and certain allied genera', Journal of South African Botany 43, 265-319.
Kativu, S. \& Drummond, R.B., 1994, 'New combination in the genus Thuranthos C.H. Wright (Hyacinthaceae) and a new record for T. macranthum (Baker) C.H. Wright in Zimbabwe', Kirkia 15, 112-116.

Manning, J.C., Forest, F., Devey, D.S., Fay, M. \& Goldblatt, P., 2009, 'A molecular phylogeny and a revised classification of Ornithogaloideae (Hyacinthaceae) based on an analysis of four plastid DNA regions', Taxon 58, 77-107.

Manning, J.C. \& Goldblatt, P., 2003, 'A new species and new combinations in Drimia (Urgineoideae)', Bothalia 33(1), 109-111. https://doi.org/10.4102/abc. v33i1.2299

Manning, J.C. \& Goldblatt, P., 2007, 'New species of Drimia (Hyacinthaceae: Urgineoideae) allied to Drimia marginata from Western and Northern Cape, South Africa', Bothalia 37(1), 183-187. https://doi.org/10.4102/abc.v37i1.313

Manning, J.C. \& Goldblatt, P., 2012, Plants of the Greater Cape Floristic Region 1: The Core Cape Flora, Strelitzia 29, South African National Biodiversity Institute, Pretoria.

Manning, J.C. \& Goldblatt, P., 2018, Systematics of Drimia Jacq. (Hyacinthaceae: Urgineoideae) in southern Africa. Strelitzia 40, South African National Biodiversity Institute, Pretoria.

Manning, J.C., Goldblatt, P. \& Fay, M.F., 2004, 'A revised generic synopsis of Hyacinthaceae in sub-Saharan Africa, based on molecular evidence, including new combinations and the new tribe Pseudoprospereae', Edinburgh Journal of Botany 60, 533-568.

Martínez-Azorín, M. \& Crespo, M., 2014, 'Validation of several species names in Hyacinthaceae', Taxon 63, 1327-1334. https://doi.org/10.12705/636.21

Martínez-Azorín, M., Crespo, M.B., Dold, A.P., Pinter, M. \& Wetschnig, W., 2015, 'New combinations and lectotype designations in Asparagaceae subfam. Scilloidea', Phytotaxa 201, 165-171.

Martínez-Azorín, M., Crespo, M.B., Dold, A.P., Wetschnig, W., Pinter, M., Pfosser, M. et al., 2013, 'Sagittanthera (Hyacinthaceae, Urigineoideae), a new buzz pollinated genus from the Eastern Cape Province of South Africa', Phytotaxa 98(2), 43-54. https://doi.org/10.11646/phytotaxa.98.2.2

Martínez-Azorín, M., Crespo, M.B., Pinter, M. \& Wetschnig, W., 2017, 'Aulostemon (Asparagaceae, Scilloideae), a new genus from South Africa', Phytotaxa 321(3), 287-293. https://doi.org/10.11646/phytotaxa.321.3.6

Martínez-Azorín, M., Crespo, M.B., Alonso-Vargas, M.A., Dold, A.P., Pinter, M. \& Wetschnig, W., 2018a, 'Austronea (Asparagaceae, Scilloideae), a new genus from southern Africa, including the description of seven new species', Phytotaxa 365(2), 101-129. https://doi.org/10.11646/phytotaxa.365.2.1

Martínez-Azorín, M., Crouch, N.R. \& Crespo, M.B., 2018b, 'Vera-duthiea zebrina (Asparagaceae, Scilloideae), a new species from eastern South Africa, and a first genus record for southern Africa', Phytotaxa 375, 283-289.

Mavrodiev, E.V., Martínez-Azorín, M., Dranishnikov, P. \& Crespo, M.B., 2014, 'At least 23 genera instead of one: The case of Iris s.l. (Iridaceae)', PLOS One 9(8), 1-8. https://doi.org/10.1371/journal.pone.0106459

Müller-Doblies, U. \& Müller-Doblies, D., 1996, 'Revisionula incompleta Ornithogalorum Austro-Africanorum (Hyacinthaceae), Feddes Repertorium 107(5-6), 361-548. https://doi.org/10.1002/fedr.19961070511

Pfosser, M. \& Speta, F., 1999, 'Phylogenetics of Hyacinthaceae based on plastid DNA sequences', Annals of the Missouri Botanical Gardens 86(4), 852-875. https://doi. org/10.2307/2666172

Schlechter, F.F.R., 1897, 'Decades plantarum novarum austro-africanarum', Journal of Botany, British and Foreign 35, 428-433.

Snijman, D., 2013, Plants of the Greater Cape Floristic Region 2: The extra Cape Flora Strelitzia 30, South African National Biodiversity Institute, Pretoria.

Speta, F., 1998, 'Systematische analyse der Gattung Scilla L. s.l. (Hyacinthaceae)', Phyton 38, 1-224.

Stedje, B. \& Thulin, M., 1995, 'Synopsis of Hyacinthaceae in tropical East and North-East Africa', Nordic Journal of Botany 15(6), 591-601. https://doi.org/ 10.1111/j.1756-1051.1995.tb02127.x

Turland, N.J., Wiersema, J.H., Barrie, F.R., Greuter, W., Hawksworth, D.L., Herendeen, P.S. et al. (eds.), 2018, 'International code of nomenclature for algae, fungi, and plants (Shenzhen code) adopted by the Nineteenth International Botanical Congress Shenzhen, China, July 2017', Regnum Vegetabile 159, Glashütten, Koeltz Botanical Books.

Van Jaarsveld, E.J. \& Eggli, U., 2016, 'Correction of a nomenclatural problem in Cotyledon (Crassulaceae), and notes on the taxonomy of miscellaneous succulent Hyacinthaceae', Bradleya 34, 142-143. https://doi.org/10.25223/brad. n34.2016.a4

Wright, C.H., 1916, 'Thuranthos macranthum', Kew Bulletin 1916, 233. 